\title{
Using technology in human trafficking: international law perspective and reflections within Middle Eastern countries
}

\author{
Yaser Khalaileh* and Nazzal Kisswani \\ College of Law, \\ Qatar University, \\ P.O Box 2713 Doha, Qatar \\ Email: Khalaileh@qu.edu.qa \\ Email: nkisswani@qu.edu.qa \\ *Corresponding author
}

\begin{abstract}
Human trafficking represents a serious violation of human rights, dignity and freedom. Many states have attempted to develop effective policies to combat human trafficking. The UN, as well as the European Union and the European Council, strived to develop policies and regulations in criminalising human trafficking, and have made a real progression in the judicial procedures needed to protect the victims of trafficking and in the process of rehabilitating them. The adoption of the Protocol to Prevent, Suppress and Punish Trafficking in Persons, Especially in Women and Children of 2000, is possibly one major cornerstone in this respect. This study aims at analysing the possible effectiveness of these contributions, and others, to include mainly the fact that human trafficking is now widely operated through the use of internet and other technology means. The extent of trusting the statistical information provided by states about human trafficking via the internet places a serious problem. Also, the limited scope of the rules of international law governing the issue of human trafficking via electronic means is just another problem. It is suggested that while there are obvious international law rules governing the crime of human trafficking in general, they nonetheless do not provide an integrated model for eliminating human trafficking via the internet, or even sufficiently hold the perpetrators of such crimes accountable for their crimes, and do not contain effective punitive measures.
\end{abstract}

Keywords: human trafficking; internet; cyber crime of human trafficking; international law; international organisations; national laws.

Reference to this paper should be made as follows: Khalaileh, Y. and Kisswani, N. (2015) 'Using technology in human trafficking: international law perspective and reflections within Middle Eastern countries', Int. J. Technology Policy and Law, Vol. 2, No. 1, pp.27-54.

Biographical notes: Yaser Khalaileh is an Associate Professor and attained his $\mathrm{PhD}$ in Public International Law from the University of West of England (UWE), and the LLM from Bristol University. He worked at Amman Arab University for Graduate Studies, Amman, Jordan as the President Assistant for Educational and Cultural Relations, whilst acting as the Deputy Dean of the Higher College of Legal and Political Studies, and during which has supervised many Masters and $\mathrm{PhD}$ students. $\mathrm{He}$ is now an Associate Professor of International Law at the College of Law, Qatar University. He is a practicing advocate, and a legal consultant for the European Environmental Program in Jordan and for the National Resources Authority in Amman. His main areas of 
research and overall interests are related to international law through an inter-disciplinary approach to cover, amongst others, the following themes: environmental protection, human rights, international humanitarian law and intervention and the use of force.

Nazzal Kisswani is an Assistant Professor of Law and attained his $\mathrm{PhD}$ in Business Law from Macquarie University, and a Master in International Trade and Commerce law. He worked at Amman Arab College, and currently an Assistant Professor of Business Law at the College of Law, Qatar University. $\mathrm{He}$ is an intensive researcher who has published several papers in peer reviewed journals. His main areas of research and overall interests are related to international law through an inter-disciplinary approach to cover, amongst others, the following themes: commercial law, business law, corporate law and technology law.

\section{Introduction}

The enormous development of technology over the past few decades, and human-beings utmost dependence on using the internet on a daily basis, had the greatest effect on increasing the rate of trafficking in humans. This crime is a serious violation and has an outrages negative impact on human rights, dignity and freedom. It is now with no-doubt an international phenomena with a negative effects on all ingredients of the international community.

Therefore, many states attempted to develop effective policies to combat human trafficking. The United Nations, as well as the European Union and the European Council, had all strived to develop a series of documents that may now be considered as an undeniable reference in the criminalisation of human trafficking. The Convention of the Council of Europe on the fight against trafficking in human beings of $2005^{1}$ developed the most important principles in criminalising human trafficking and has made a real progression in the judicial procedures needed to protect the victims of trafficking and the process of rehabilitating them, as well as drawing broad guidelines for improving international judicial cooperation to achieve this aim. This convention also included the roles of relevant authorities and governmental institutions, civil society organisations and non-governmental organisations, in the fight against various crimes of human trafficking, especially of women and children.

The adoption of the Protocol to Prevent, Suppress and Punish Trafficking in Persons, Especially in Women and Children of 2000, additional to the United Nations Convention against Transnational Organized Crime of 2000, was the first long-awaited outcome of the international community endeavour in this respect. For more than a decade, the international organisations, both governmental and non-governmental, and in coordination with the states that have shown particular interest in the subject of human trafficking, have worked hard to revise the means and resources necessary for eliminating human trafficking.

Therefore, this study aims at analysing the possible effectiveness of these contributions in light of the challenges that may face the work of such organisations, to include mainly the fact that human trafficking is now widely operated through the use of internet and other technology means. The extent of trusting the statistical information 
provided by states about human trafficking via the internet places a serious problem. Also, the limited scope of the rules of international law governing the issue of human trafficking via electronic means is just another problem. It is suggested that whilst there are particular international law rules pertinent to the crime of human trafficking in general, they nonetheless do not provide an integrated model for eliminating human trafficking that takes place over the internet. These rules do not sufficiently hold the perpetrators of such crimes accountable for their crimes, and do not contain precise or effective punitive measures to practically combat this crime. Therefore, the sufficiency of this legal system to create the desired change on the national legal policies of states is doubtful. The Middle-East countries are no exception.

\section{The challenges pertinent to fighting human trafficking}

In 2008 , the ILO stated that there were approximately 12.3 million people working as forced labourers who have been trafficked both domestically and internationally. ${ }^{2}$ There is no doubt that most of these crimes are done using the internet. As such, it seems that human trafficking has greatly attracted the attention of activists who have normally outlined their views on the possible embedded challenges in producing a coherent study on this phenomenon, and its deteriorative impact. These obstacles can be one, or the sum, of the following two frames.

\subsection{Political and cultural challenges}

Internal political and cultural pressures may well be a determinative cause in preventing some states from shedding light on certain types of societal crimes. Human trafficking, especially trafficking in prostitution, though it presents a violation of fundamental human rights, reflects a sham on which certain states have long avoided publishing statistics for both political and cultural reasons. Religious activists have denied the existence of such crimes within their respective countries. Official statistics declined from presenting a real measurement of the gratitude of the phenomena. This attitude, however, has changed markedly in recent years. States became more sensible in providing realistic information and statistics given the fact that trafficking in humans has become epidemic and beyond national control. As such, information started pouring on a voluntary basis to the United Nations Secretariat, though still not sufficient or comprehensive in content. ${ }^{3}$ The insufficiency of the information provided could well be attributed to the fact that trafficking in prostitution is one of the crimes which discourage the victims themselves, particularly women, from reporting the crimes they get involved in.

The ILO has estimated that $2 \%-14 \%$ of the national income for some countries like Indonesia, the Philippines, Malaysia and Thailand is yielded from sex tourism, a matter which precludes providing real figures on crimes related to this type of tourism, ${ }^{4}$ in addition to the financial benefit for judicial officers for condoning such crimes as in some countries such as Italy and India. ${ }^{5}$

In fact, it seems that the issue is a complex one given the fact that the most states do not possess a solid logistics, or sometimes administrative capabilities or infrastructure needed, to fight trafficking in humans. Some even find hardship in preparing proper reports on the gravity of this type of crime within their territories given the fact that 
national statistics are bound to be rendered imprecise when trafficking is committed online.

\subsection{Legal challenges}

Although trafficking in humans, especially for prostitution, is not a novel product of the present time, as its roots go back to the beginning of human history, using the internet for this end is an innovation. The internet is now used to achieve maximum and quick revenues in this business. Yet, because law and regulations related to the use of internet in general are still in their embryonic stage, prosecuting perpetrators of trafficking in humans becomes a blurry issue specifically when the crime is of a transnational effect, a matter which has encouraged, and is still encouraging trafficker in humans, specifically prostitution gangs, to grow more into their trade fearless of being arrested. ${ }^{6}$

As such, many states have sought issuing national laws criminalising acts related to industry of sex trafficking, in particular those related to children trafficking, even if such crimes are committed via the internet. ${ }^{7}$ A real difficulty stands still in the face of these endeavours; The inability of the prosecuting authorities to initiate proceedings in light of the idea of 'the right to privacy' and the constitutional guarantees of the freedom of communication in general and the ever increasing emergence of rules pertinent to the freedom of communication over the internet. These basic rights are intensely monopolised by the perpetrators of human trafficking and are normally considered as a safe haven to commit their crimes. Hence, the importance of supporting the executive authority with the required latest internet related equipment and training to fight this type of crime becomes a necessity, ${ }^{8}$ in particular when these crimes are committed outside the borders of the state. ${ }^{9}$ For this reason, some states tend occasionally to communicate the legal evidence they get to collect to Interpol to be communicated to the concerned state as long as the law of the latter state criminalises such acts. ${ }^{10}$

In fact, the real lack lies not in legislations to fight the crime of human trafficking, but in the ability to apply the existing legislations on new crimes committed online using modern technological development. Another real difficulty is to collect evidences on such types of crimes, a matter which prompted some European countries such as the Netherlands, France and Belgium, to consider the issuance of procedural legislations to enable the authorities to conduct the requisite investigation using appropriate technological tools. ${ }^{11}$

One encouraging element for the continuity of this crime is the fact that these crimes are normally committed by many participants with the power of gangs to target overseas victims. The globalised nature of this phenomenon allows a room for jurisdictional complexities, and even more importantly the problem of enforcement of judicial decisions, if any, against the perpetrators of these crimes. ${ }^{12}$

Therefore, the importance of this study is to also examine the possibility of achieving international cooperation in fighting the phenomenon of human trafficking via the internet, in the absence of international law that directly criminalises the use of internet in exploit human beings for prostitution purposes or for any other illegal use. It can be noted that criminalising trafficking in humans via the internet is absent from the UN Protocol to Prevent, Suppress and Punish Trafficking in Persons, Especially in Women and Children of 2000, though addresses the issue of human trafficking in general. Ordinarily, one may think that the Protocol illegalises human trafficking in a general fashion and that includes trafficking in whatever means used. Yet, it could be argued that this generalisation is 
lacking when noticing that almost all trafficking in humans is now perpetrated through the use of the internet. Singling out a special international legal regime in criminalise trafficking whose main means is the internet becomes a necessity. Others may also argue that these particular crimes might be properly attended to through the 2001 Cyber Crime Convention $^{13}$ as an effective and adequate tool, particularly for those crimes that relate to the online sexual exploitation of children. ${ }^{14}$ However, this Convention does not clearly criminalise the use of the internet for children trafficking, or even selling them for sexual forced labour. Also, no reference was made to the issue of sexual exploitation of women who do not consent to their exploitation. Moreover, this Convention cannot be narrowly classified as an international one as it is merely a production of the Council of Europe, although made open to all states for membership.

\section{International efforts in fighting typical human trafficking}

Human trafficking is an international social phenomenon that has negative effects on the entire international community; therefore, we cannot turn a blind eye on its existence in all countries regardless of their level of development. Indeed, human trafficking is the third largest criminal activity after drugs and weapons trade, and is also the fastest to grow. The ILO estimates the volume of human trafficking to be two million people trafficked cross-border each year, the majority of them are women and children, the profit from the sexual exploitation of women and children is estimated at $\$ 28$ billion annually. ${ }^{15}$

As such, few initiatives have surfaced on the international scale as a normal repercussion to the gravity of the situation both within the United Nations and at the regional level, particularly in the European Union and the Council of Europe. These initiatives are considered as the cornerstone for an international system on which we can rely in fighting this phenomenon. The main concern was to identify the most effective measures of criminal policy for fighting and preventing the crime via introducing relevant international legal framework for incriminating human trafficking. As a result, the 1904 International Agreement for the suppression of trafficking in women and children merged as the first international document in this respect, ${ }^{16}$ and the Convention for the Suppression of Trafficking in Women and Children ${ }^{17}$ was soon adopted, and followed by the International 1933 Convention for the Suppression of Trafficking in Women of full age and later by the Convention for the Suppression of Trafficking in Persons and the Exploitation of Prostitution. ${ }^{18}$

All previous attempts paved the way for the 2000 United Nations Convention Against Transnational Organized Crime to emerge, and subsequently the additional Protocol to Prevent, Suppress and Punish Trafficking in Persons, Especially in Women and Children, as well as the International Protocol Against Illegal Trafficking in Migrants on Land, Air and Sea. ${ }^{19}$ These attempts aimed at achieving one common goal, namely, to promote cooperation between states in the prevention and control of transnational organised crime, as mentioned in article (1) of the Palermo Convention. The Convention's Preamble expressed the main objective of the treaty that is to deprive perpetrators of transnational organised crime from any safe haven, and the necessity to prosecute them for their illicit crimes wherever committed, and in cooperation between all state parties. 
In fact, in this respect, a number of international conventions have emerged since the beginning of the twentieth century, which all have reflected the members' agreement on the necessity to adopt criminal policies, and specifically in prevention of women and children trafficking. These conventions generally incorporate transnational crimes, specifically human trafficking, as having a negative impact on all states, and as crimes that explicitly violate internationally agreed human rights perceptions. These conventions include the 1926 Convention on Slavery; the 1930 ILO Convention on Forced Labor (No. 29); the 1951 Convention on Refugees 1951; the 1957 ILO Convention on abolition of Forced Labor (No. 105); the 1979 Convention on the elimination of all Forms of Discrimination against Women; the 1989 Convention on the Rights of Childs; the 1990 Convention for the Protection of Migrant Workers and their Family Members; the 1999 ILO Convention on the Worst Forms of Children Labor (No. 182); and the 2000 Protocol on the Involvement of Children in Armed Conflicts.

In Europe, besides the numerous recommendations passed by the European Committee of Ministers, ${ }^{20}$ few important documents were adopted and are pertinent to the trafficking in persons issue. These include: the 1951 European Convention on Human Rights; the 1997 European Convention for the elimination of all forms of Discrimination Against Women; the 1996 European Council Convention on Children's Rights; and the 2005 European Council Convention on Action against Trafficking in Human Beings. ${ }^{21}$

The latter Convention has indeed helped in creating an impetus for the state parties to consider the crime of human trafficking as a serious crimes that deserves confrontation and a commitment to seek appropriate criminal policies, and to enforce the necessary techniques to achieve the necessary protection to victims at the national, regional and international levels. The Convention also included signals for the member states to use specific methods and strategies for the suppression of human trafficking and to apply suitable means in fighting corruption on this crime, in conjunction with developing anti-poverty policies. The idea was to transform human trafficking from being an investment of a 'limited risks and high financial revenue' to a 'high risk investment with little financial revenue'. Therefore, in order to achieve this goal, all concerned organs and law enforcement agencies should seek to use all means to prevent this crime and to diminish the profitable practices involved in human trafficking, and to rely on confiscation of relevant profits that have materialised in the process of relevant crimes. ${ }^{22}$

Besides this, various international organisations have also strived to fight human trafficking., who have attempted to clarify the crimes entailed both in definition and content. In this respect, article (3) of the 2000 Protocol to Prevent, Suppress and Punishment Trafficking in Persons, in supplement to the UN Convention against transnational organised crime, has made an attempt to define trafficking by stating that: of organs. 
b The consent of a victim of trafficking in persons to the intended exploitation set forth in subparagraph (a) of this article shall be irrelevant where any of the means set forth in subparagraph (a) have been used.

c The recruitment, transportation, transfer, harboring or receipt of a child for the purpose of exploitation shall be considered 'trafficking in persons' even if this does not involve any of the means set forth in subparagraph (a) of this article.

d 'Child' shall mean any person under eighteen years of age."

The abovementioned definition can be considered as a special leap in the fight against human trafficking where it was agreed on the comprehensive definition and expanded scope for 'human trafficking' to include all means of forced labour and all the circumstances of sexual exploitation. Here, one can notice that the convention included sexual exploitation and compulsion in its protocols, but not the differences between the forced labour or sexual exploitation on one hand and slavery or related servitude offences on the other. In this context, article (e4) of the Council of Europe Convention on the special procedures to prevent human trafficking of 2005 gives a similar definition to the United Nations Convention in giving more detailed definition to meaning of a 'victim' in human trafficking, by indicating that all natural persons who become subjects to trafficking should enjoy every protection measures needed. ${ }^{23}$

In light of this, one must conclude the answers of few essential elements: Are victims of human trafficking considered as slaves?; Is it possible to identify the most active websites and channels of sexual trafficking so as to conclude the exact course of action in human's trafficking?; Are states that have signed the Protocol convinced that they should have special legislative measures to combat these crimes and to meet their duties in as set in the Protocol?. ${ }^{24}$

These questions are intertwined with what seems to be a confusion between human trafficking and slavery. Clearly, one must confess that human trafficking represents the most hideous crime since human beings themselves represent the goods of one of the most profitable transactions. Buying and selling of humans, whether forcibly or voluntarily, is made possible because of the shear need of the subjects who would normally seek jobs that would enable them to support their dependents in providing them with the minimum level of living standards. It is always going to be an easy task to recite thousands of stories of painful realities of illegal immigrants that have sold themselves to gain access to countries they considered as a shelter. Yet, the receiving states usually consider those as illegal immigrants, and would duly apply special rules on them which in effect are no more than the national rules related to smuggling, immigration or asylum, without paying attention to the fact that the immigrants may have been subjected to abduction and to forced transportation before they are sold to work in various market fields such as housekeeping services, agriculture services, factories or even prostitution.

The confusion between human trafficking and other related crimes, such as illegal immigration, smuggling and slavery, stands as loophole in various national legal systems. This confusion represents a challenge for researchers and activists in the fight against human trafficking. For example: Would women seduced through the internet, or other means, to voluntarily accept traveling abroad and work in prostitution considered as illegal immigrant, and therefore only apply the illegal immigration rules upon them? Would it be possible to change the applicable criteria if only it turns to be that the promised working conditions are contrary to what has been agreed upon? Or can we 
simply apply the rules akin to slavery on all such acts, knowing that these rules are more settled as rules in both international law and national legal systems?

One can only conclude that the mere application of national law and regulations on illegal immigrants is one which is characterised by complexity. These rules, are most developed in countries that attract more illegal immigrants, and who possess particular institutions concerned with immigration that seek improving their financial situation. The USA is just one apparent example. ${ }^{25}$ The US Congress defined to involve "the recruitment, harboring, transportation, provision, or obtaining of a person for the purpose of a commercial sex act in which a commercial sex act is induced by force, fraud, or coercion, or in which the person forced to perform such an act is younger than age $18,{ }^{26}$

It appears from this definition that it focuses on deception, fraud, or coercion as elements of the crime, without paying attention to voluntarily immigrants who accept the risks associated with illegal immigration. Though it is possible to consider the mere attraction of human through the internet for whatever commercial venture as voluntary, however, for the purpose of this study, a definite distinction blurs and therefore should not be upheld. Indeed, using the internet is destined to be a voluntary action and never a forced one, this research, however, attempts to cover both forced and volunteered individuals in carrying out forced labour, and as a result human trafficking is concluded. This is pursuant to article 3 of Palermo Protocol which concludes the same result especially in relation to children and women labour.

Despite the apparent confusion between human trafficking and the modern manifestations of slavery there have been some scholarly valuable efforts to clear this confusion. Many studies analysed the new manifestations of slavery, for example, a study by Bales identified the core differences between old and contemporary slavery, and concluded that classic slavery required the involvement of ownership deeds of one person over another, and that in spite of the disappearance of this legal requirement in modern times, the use of force, whether directly or indirectly in the employment process of human trafficking, and the sheer ability to control the trafficked individuals because of their need, and due to the absence of government role in prevention, would simply render these acts unaccountable for. ${ }^{27}$

Indeed, scholars have attempted to provide a comprehensive definition of the concept of modern slavery so as to include contemporary hegemony and exploitation of individuals. Splitting views, however, about considering human trafficking as slavery. Gallagher, for example, was in the opinion that the definition contained in the UN Convention on Slavery of 1926 stipulates 'acquisition' as an element of servitude, and that countries refused to waive this requirement in dealing with slavery since then. ${ }^{28}$ This opinion, if proven right, means that trafficked people who are under control and exploitation of traffickers are not considered slaves as long as there is no proof of being acquired by the trafficker. This result leads to the exclusion of most human trafficking acts via the internet on the basis that this kind of trafficking does not create any type of acquisition.

In fact, despite the fact that international law did not classify the victims of human trafficking as slaves in any of the mentioned conventions, a different outcome that has been reached by Gallagher can still be reached. If we are to take into account the capacity and the manner of violation of human rights, which coincide with acts of human trafficking, and what is included in the various international instruments to protect these rights, we ought to note that international law considers committing the crime of human 
trafficking just as heinous as committing the crime of slavery. The continuous development of international law, that is seemingly striving to combat all forms of human trafficking, and the work of activists in this respect, provide a clear picture of how human trafficking acts are committed, and that the degree of violence and deprivation that is inflicted on the humans trafficked. As such, human trafficking can well be considered as just one form of modern slavery. It must not be forgotten the conclusions reached by Roma Institutions pertinent to combating human trafficking, that this crime might just contain acts of leasing brothels that would inevitably enable brothel owners to claim ownership over trafficked humans as slaves, even in the absence of a pre-determined or

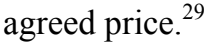

Naturally, we cannot neglect various types of trafficking that take place on a daily bases via the internet and in which human beings are the subject of the trade. Leasing humans in the intention of selling them, and in the absence of national and international regimes, would definitely fall into the ambit of the slavery phenomenon. As such, human trafficking may only be deemed as slavery in new dress. For instance, the indirect ownership of humans can be easily proved once we look into the chain of activities followed by the maids service companies. The acquisition of passports, and other related identity documents, by the company, and forcing the subject to pay the expenses of travelling from and to his own country, and then forcing him to work in a remote factory in harsh conditions, would all amount to a servitude that grows to be slavery. This is even when the trafficked person has the knowledge and prior information with the nature of the required work.

It must be also pointed out here that there is a mutual benefit between electronic trading and online sex trafficking. Kara describes this mutual benefit in concluding that the sex industry was responsible for the development of technology and the internet in the last decade. ${ }^{30}$ Joyce adds that traffickers before the internet had to travel over all the world to buy women with the intention to be used in prostitution and slavery, and the development of the internet has made it easier and more effective to them to conclude their trade through a simple use of modern technology, whereby most recent photos of the employed girls are easily downloaded, and where bidding through the internet would conclude the deal, away from the risks of cross-border movement with the concealing of the identity of the perpetrators. ${ }^{31}$

\section{International efforts in combatting trafficking in humans via the internet}

Numerous organisations work constantly to be kept up-to-date with the developments that take place in the electronic cyberspace security. Working groups were established to develop specific strategies in fighting internet crimes. The term 'cyber security' is usually used to summarise the activities of these groups in their operations in gathering relevant information and suggest relevant policies for the secure flow of information. They would also develop security measures needed and specific guidelines for managing predicted risks, protection, training, and the best professional practices to protect individuals from crimes committed through the internet. ${ }^{32}$ 


\subsection{Efforts of international organisations}

A summary of the most prominent international organisation that have dealt with human trafficking via the internet in one way or another could well be the following.

\subsubsection{The group of eight (G8)}

Ministers from the eight major industrialised nations, the G8, seem to be in agreement on a plan to fight international computer crime. Interior and justice ministers of Britain, Canada, France, Germany, Italy, Japan, Russia and the USA have expressed their views in strong terms. The main idea professed is that criminals were no longer restricted by national boundaries and all countries had to act together if they wanted to combat cyber crime. Agreements were reached to tackle paedophilia, drug-trafficking, money-laundering, electronic fraud, computerised piracy, industrial and state espionage. It was also agreed that the most important measure to tackle these offences is a commitment to train law enforcement officials in the tools of the cyber trade, and to coordinate prosecution efforts so that countries know where to try a cyber criminal. Ministers also pledged to create a 24-hour-a-day contact service to help national police forces respond quickly and in a concerted manner to fast-moving cyber criminals. Other measures in the ten-point action plan include judicial cooperation and agreements on extradition, hastening the progress of mutual agreements, speeding up communication, provision of standards for secure telecommunications and developing forensic standards for retrieving electronic data. ${ }^{33}$ Indeed, the G8 has adopted many policies aimed at fighting the internet related crimes. These have all been based on the dictum that online criminals should enjoy no safe haven, and the necessity to promote the required level of coordination among all state parties in prosecuting the perpetrator of internet crimes regardless of where the damage has occurs, as well as the necessity to training entrusted officials with the enforcement of law after equipping them with the latest tools necessary to fight high-tech crime.

The G8 has called upon the international community to develop adequate international solutions by means of developing appropriate treaties to this end. To do so, the G8 has produced numerous studies about the best practices possible in fighting human trafficking to cover: the principles and action plan on high-tech crime and computer crimes in 1997; a study on the principles of access to information stored on computers outside the national borders in 1999; recommendations on the interception of communications and networks off national borders in the fight against terrorism and criminal investigations in 2002; and the basic principles for providing the basic data to protect public safety in $2002 .^{34}$

The main recommendations of the G8 on computer-related crimes may be summarised to include the criminalisation of internet based human trafficking; addressing problems of judicial investigations through effective training; promoting international cooperation in taking deterrent steps to prevent high-tech crime; the involvement of industrial sector in the fight against trafficking; enacting and implementing laws to ensure the appropriate protection of intellectual property rights against counterfeiting and piracy; public awareness of high-tech crime; and an appropriate capacity building for investigating and prosecuting criminals. ${ }^{35}$

Much of the above however is now on the way of development. Interpol have now established the "Interpol Global Complex for Innovation" IGCI, which is an \$8 billion 
facility located in Singapore opened in late 2014, and is staffed by law enforcement from all over the world. The focus on the IGCI, is to collectively target cyber crime. Much of their function is going to surpass much of G8 direction as the material referenced is 12 to 17 years behind. ${ }^{36}$

\subsubsection{The United Nations general assembly}

The United Nations has issued several decisions concerning the safety in using technology and the internet, and declared standards for the desired protection. The most important decisions can be summarised as follows:

- Resolution. $45 / 121$ of 1990 on crime prevention, ${ }^{37}$ as well as publishing a guide to prevent and combat crimes related to computers in 1994.

- Resolution no. 55/63 of 4th December 2000 and 56/121 of 19th December 2001 on combating the criminal misuse of information technologies. ${ }^{38}$ This decision aims to encourage Member States to develop national legislations for fighting the criminal misuse of information technologies, recommending the establishment of a Commission on crime prevention and criminal justice.

- Resolution no. 57/239 on 20th December 2002 on creating a global culture of cyber security. ${ }^{39}$

- Resolution no. CCPCJ 16/2/07 of April 2007 on the effective prevention of crime and criminal justice to fight the sexual exploitation of children. ${ }^{40}$

One particular conference of relevant importance was the United Nations Eighth Congress on the prevention of crime and the treatment of prisoners held in Havana in 1990. On computer-related crimes, the Congress emphasised the importance of combating computer-related crimes specifically when used for organised crimes committed by gangs in human trafficking and particularly to facilitate the prostitution of children. The Conference focused on the need for cooperation between states to fight this type of crime, which is growing day by day, especially those relating to the porn programmes and programmes exchanged between computers, as well as the negative use of computers and the internet by organised crime gangs with a view to facilitating child prostitution. $^{41}$

\subsubsection{The International Telecommunication Union}

International Telecommunication Union (ITU) comprises 192 countries and 700 companies from the private sector in addition to academic institutions. This Union is an important centre for cooperation amongst the members for being one of the UN specialised agencies, devoted to helping state governments and industries once they agree on specific common principles or an entire agreement. This Union is particularly useful when information technology and telecommunications infrastructures is the essence of agreements. ${ }^{42}$ To this end, the Union has developed a scheme that aimed at enhancing the level of security in the face of cyber misuse. This online cyber security scheme consists of seven main goals that could be summarised as follows: ${ }^{43}$ 
- developing strategies for the development of a model cyber legislations online to be applicable nationally and internationally, in parallel with the adopted national and international legal measures

- developing strategies with common grounds applicable nationally and regionally that aims at institutional structuring and capacity building and effective policies that could further the deterrence of internet related crimes

- the determination of an agreed international minimum level on security standards and systems of software applications

- developing strategies to develop a global mechanism for monitoring, early warning and response while ensuring coordination across borders

- developing strategies to create and apply a global digital identity system, defining organisational structures required to ensure the recognition of digital documents of individuals across geographical borders

- developing global strategy to facilitate building human and institutional capacities for the promotion of knowledge and know-how in various sectors and in all cyber areas

- $\quad$ providing advice on the possible adoption of a global strategic framework for stakeholders to create international cooperation and dialogue, cooperation and coordination in all above-mentioned areas.

\subsection{Human trafficking via the internet in international conventions}

The imperfection of international law, as indicated in the foregoing analysis, is to a great deal magnified when the issue is related to human trafficking via the internet. Nevertheless, one can only enumerate the conventions that could mainly be related to this issue, and conclude the efforts that have been made by the international community in general, or of the European States in particular. These conventions are: the Protocol to Prevent, Suppress and Punish Trafficking in Persons, Especially in Women and Children of $2000 ;{ }^{44}$ the Cyber Crime Convention of 2001; the ILO Convention on the Worst Forms of Child Labor of 1999; and the Inter-American Cooperation Portal on Cyber Crime of 1999.

\subsubsection{The Protocol to Prevent, Suppress and Punish Human Trafficking of 2000}

As mentioned above, some consider human trafficking no less than a modern form of slavery, ${ }^{45}$ and therefore is already criminalised for a long time on a universal level. Yet, although the phenomenon of slavery has been legally encountered, its symptoms still survive in almost all states whether openly or implicitly, and most obviously felt in the exploitation of men, women and children, in prostitution. ${ }^{46}$ Hence, as is suggested by the its title, the 2000 Protocol aimed at preventing, suppressing and punishing human trafficking, especially when women and children are at stake.

This supplementary Protocol to the UN Convention on transnational organised crime provided a comprehensive definition of sex trade. It has included in articles 3 to 9 what clearly indicates to the criminalisation of the exploitation through prostitution or any other form of sex exploitation, after having provided a clearer definition of human 
trafficking. It has also stressed the right of all victims, specifically children and women, to be protected from being subjected to trafficking, requiring all states to take impose appropriate interim measures to abate the factors that lead to exploitation such as poverty, underdevelopment and lack of equal opportunity. ${ }^{47}$

One obvious advantage of this Protocol is its clarification that the victims' consent or submission to human trafficking does not annul the crime or required preventative measures against the crime. It also gives the victims the right to resort to national courts to claim compensation for any suffered damage, and they are free to choose either to remain in the state they were trafficked or to return to their home countries. However, this Protocol fails to address fighting human trafficking in children and women particularly through the use of technology, as one of the fastest growing types of crimes prevalent online. This is despite the EU's belief that the definition of trafficking contained in the Protocol covers all types of trafficking, even those made over the internet. Indeed, the overall and general definition contained in the Protocol does not really cover the most important means and tools used in this particularly overwhelming crime. Technology used for human trafficking, in advertising for pornography, porn-websites and sex-tourism, normally charging high fees to access directed and spam websites, cannot be simply ignored.

\subsubsection{The Council of Europe Convention on Cyber Crime ${ }^{48}$}

This Convention is an international treaty that aims at achieving harmonisation of member states national laws on Cyber Crime. It also seeks to improve the national capabilities in investigating related crimes, and attempts to provide for the cooperation necessary on investigations. ${ }^{49}$ This Convention contains procedural provisions which indicates that it is not limited to Cyber Crimes but also extends to any crimes for which it is necessary to collect evidence in 'electronic form'. ${ }^{50}$ As such, this Convention obliges member states to incorporate related laws in a way to allow effective enforcement; to search and seize computers and to access computer data; to engage in interception; and to obtain real-time and stored communications data, whether or not the crime under investigation is a cyber crime. ${ }^{51}$

The European Council has classified the internet crimes into four different types: crimes against the integrity and privacy of information, and computer-related crimes, and crimes relating to computer content, and crimes concerning trademarks and intellectual property. It is noted that this Convention has defined crimes relating to content to be those which include any sexual or pornographic content or any pornographic material relating to children. The first paragraph of article 9 of the Convention state the offences related to child abuse material and the obligation on all states to adopt "such legislative and other measures as may be necessary to establish as criminal offences under its domestic law, when committed intentionally and without right, the following conduct:

a producing child pornography for the purpose of its distribution through a computer system

b offering or making available child pornography through a computer system

c distributing or transmitting child pornography through a computer system

d procuring child pornography through a computer system for oneself or for another person 
e possessing child pornography in a computer system or on a computer-data storage medium."

The Convention defines the concept of child-related pornography as being any pornographic material including those visually presented involving minors in sexual conduct, or where a minor is exploited in any sexual behavoiur, or in fictional or realistic images representing a minor in sexual conduct. The convention defined the minor as anyone under the age of $18 .^{52}$

Given the overall objective of the Council of Europe to achieve greater unity between its members in the fight against cyber crime by developing legal norms as a basis for public information law, this Convention concluded from its members' conviction that it provides the necessary procedures to deter any action directed against confidentiality, integrity and availability of computer systems, networks and data and to take adequate actions and powers to fight such crimes. ${ }^{53}$

Finally, it is to be noted that the Convention's preamble has affirmed the necessity to take legislative and regulatory measures to ensure prosecution of perpetrator of crimes related to the use of the internet, and to provide the appropriate rules for investigation and prosecution, with special emphasis on the importance of local, regional and international cooperation and the necessity to create balance between the requirements of enforcing the law and the respect of fundamental rights and involved sovereignties.

\subsubsection{The Inter-American Cooperation Portal on Cyber Crime of 1999}

In 1999, several international bodies and organisations held an international conference at the University of Stanford which brought together legal representatives to enhance the protection from terrorism and related computer crimes. This initiative was arose in recognition of the spread and potential magnitude of cyber crime for OAS member states, and recommended the creation of an intergovernmental expert group, within the framework of the OAS, with responsibility for: completing a diagnosis of criminal activity which targets computers and information, or which uses computers as the means of committing an offense; completing a diagnosis of national legislation, policies and practices regarding such activity; identifying national and international entities with relevant expertise; and identifying mechanisms of cooperation within the inter-American system to combat cyber crime. ${ }^{54}$ In conclusion, article 2 of the convention reflected the requirement that member states should adopt uniform standards to face these crimes and to impose penalties commensurate with their degree of danger. Article 3 has set out computer-related crimes such as the unauthorised access, edition, and deletion of data with the aim of harming the institutions that own these services or the delete or change of data for the purpose of giving false information that could cause material damage. Also, article 4 covered the related crimes such as, aiding, abetting, seducing or conspiring to commit cyber crime, whereas article 5 about the jurisdiction of the member states to take appropriate legal action. Finally, article 126 stipulated the necessity of cooperation between the member states in the prosecution process, joining the treaty and the submission of annual reports to the Inter-American Association of Independent Information Professionals (AIIP). ${ }^{55}$ 


\subsubsection{The Convention for the Protection of Individuals with regard to Automatic Processing of Personal Data of $1981^{56}$}

The European Council plays a prominent role in the field of computer-related crimes, especially in the area of maintaining individual data concerning the people's private lives, through developing appropriate recommendations and holding conventions reflected in its by-laws to address all the novel matters in scientific progress. The most important work of the Council in this respect is the Convention 108 of 1981 which is divided into seven chapters that include general provisions and the basic principles for data protection and the transmission of information outside the members state's borders, as well as the mutual cooperation required between them. This Conventions sets an Advisory Committee and allows amendments to be proposed by the members, and includes final important provisions.

Article 1 defines the purpose of this convention in being to secure in the territory of each Party for every individual, whatever his nationality or residence, respect for his rights and fundamental freedoms, and in particular his right to privacy, with regard to automatic processing of personal data relating to him ('data protection'). Article 2 sets out the meaning 'personal data' as being any information relating to an identified or identifiable individual ('data subject') and that 'automatic processing' includes the following operations if carried out in whole or in part by automated means: storage of data, carrying out of logical and/or arithmetical operations on those data, their alteration, erasure, retrieval or dissemination. The 'controller of the file' means the natural or legal person, public authority, agency or any other body who is competent according to the national law to decide what should be the purpose of the automated data file, which categories of personal data should be stored and which operations should be applied to them.

\subsubsection{The Arab Convention on Combating Information Technology Offences of $2012^{57}$}

The League of Arab States Convention on combating information technology crimes is one important regional effort in recent years to drum up the necessary security measures to fight crimes in all its forms and manifestations, including information technology crimes, by creating foundations and legal environment. The Convention aims at strengthening cooperation among the Member States to fight information technology crimes which threaten their security and interests and the safety of their communities, for being convinced of the need to adopt a common criminal policy aimed at the protection of Arab society against cyber crime, and in conformity with the high religious and moral principles, in particular the provisions of the Islamic Sharia', as well as the heritage of the Arab nation that renouncing all forms of crimes, taking into account the overall system of each state, in conformity with the Arab and international treaties and conventions on relevant human rights so that ensure, respect and protect them. ${ }^{58}$

While other regional instruments are limited to a comparatively few number of computer-related offences, others present an expansive list. The Council of Europe Cyber Crime Convention, for example, covers computer-related forgery and computer-related fraud alone. ${ }^{59}$ In contrast, the League of Arab States Model Law contains criminal provisions on the use of a computer system for forgery, threats, blackmail, appropriating moveable property or a deed through fraudulent use of a name, unlawfully obtaining the 
numbers or particulars of a credit card, unlawfully benefiting from communication services, establishing an (internet) site with the intention of trafficking in human beings, narcotic drugs or psychotropic substances, and transferring illicit funds or disguising their illicit origin. ${ }^{60}$

Article 12 of this Convention states that organised pornographic crime includes: "the production, display, distribution, provision, publication, buy, sell or import of pornographic material or violate morals using IT". The convention stressed on "the punishment for crimes relating to child and minors pornography", which stress includes stress the provisions contained in paragraph 2 of this article on the possession of pornographic material for children and minors, indecent material for children and minors via information technology or storage medium. Article 13 of the Convention stipulates for the other crimes associated with porn such as gambling and sexual exploitation. Paragraphs 3 and 4 of article 16 stipulate the crimes related to organised crimes committed through the use of information technology to include human trafficking and human organs trafficking. Also, the Convention focused on the need for legal and judicial cooperation between the Member States through their compliance to adopt the necessary measures to extend its jurisdiction over any of the crimes set forth in the Convention, if the crime "is committed in whole or in part, or occurred:

a in the territory of the member states

b on board any ship raising the flag of any member state

c on board any aircraft registered under the laws of one of States members

d by any of the state nationals if the crime is punishable under the domestic laws of the state where the crime is committed, or was committed outside the jurisdiction of any state

e if the crime prejudice any of the supreme interests of the state".

Also, the Party States undertake to adopt the necessary measures to extend the jurisdiction to cover crimes set forth in article 31, paragraph 1 of the Convention in cases where the alleged perpetrator is present in the territory of that member state and not being extradited to another member state according in the fulfilment of the nationality jurisdiction doctrine after an extradition request is made. ${ }^{61}$

\section{Domestic legislations related to human trafficking via the internet}

We have previously presented the efforts made through adopting international conventions in the field of fighting human trafficking. This section will be dedicated to reviewing the most apparent domestic legal efforts on this topic.

\subsection{Non-Arab legislations relating to human trafficking via the internet}

It is the intention here to address only the legislations in two countries that professed a pioneering model in combatting human trafficking via the internet, namely: the USA and Australia, unlike the UK and France whose legislations do not contain any provisions in this regard. 


\subsubsection{The USA}

On 5 March 2009, Thomas Dart, President of Illinois State police filed a federal case against the owners of the company 'Craigslist', one of the largest cyber companies concerned on the sex trade via women and children through its porn websites. ${ }^{62}$ The case sought to obtain compensation of US $\$ 100,000$ spent by the police to fight street prostitution and pimping and human trafficking due to the work of this company. ${ }^{63}$ Despite the successful conclusion of this case against one of the major companies in the business of prostitution and human trafficking, 'Craigslist' is only the tip of the iceberg of similar companies that do most of their business through the internet, through chat rooms pornography with girls paid for sex over the internet.

The importance of the outcome of this case lies in the fact that it was contrary to the provisions of the judicial precedents in the USA, which has supported the US policy for the freedom to use the internet, ${ }^{64}$ and has always been supported by the US Congress in the necessity to maintain open market competition policy and commerce via the internet, at the same time to encourage the fight against human trafficking. ${ }^{65}$

It seemed that the outcome of this case was due to the optimal use of the defence of some US legislation including the Communications Decency Act of 1996 (CDA); the Child Online Protection Act of 1998 (COPA); and the Children's Internet Protection Act of 2000 (CIPA).

a The Communications Decency Act of 1996 (CDA) was the first notable attempt by the US Congress in organising the work of internet pornography which was voted on 14 June 1995. A fifth section of the US Telecommunications Act of 1996 has been incorporated to this Act. This section tries to regulate both indecency (when available for children), and obscenity in cyberspace. Section 230 thereof, is interpreted as not including the internet service operators, so they are not legally responsible for the abuse by persons who use the services.

The most controversial parts of the Act are those relating to obscenity on the internet. The Act was amended by introducing new articles in response to the concerns that related to child abuse material on the internet and that has always been on increase, as obscenity has already been organised on television and radio broadcasting through the Federal Communications Commission by limiting the broadcasting hours containing offensive terms to certain hours of the day. The CDA imposed criminal penalties for anyone who knowingly uses an interactive computer service, or any means of communication, or send, comment, request, suggest, upload a photo, depict or describe indecent material on which the standards of contemporary society are applicable to people under the age of $18 .^{66}$

b The objective of Children's Internet Protection Act of 1998 was to restrict access of minors to any websites or material defined as harmful to such class of people.

However, this law has not been enforced, as it takes three judicial sessions to prevent its enforcement. It came as part of a series of efforts by US legislators to fight online porn, in response to the constitutional difficulties encountered by the aforementioned Communications Indecency Act, which was repealed in 1997 for being unconstitutional.

This Act requires the commercial providers of internet service to restrict their websites from access by minors to pornography as 'contemporary community standards'. 
However, the Federal Government was exempted from the enforcement of this Act, by order of the Third Circuit of the Court of Appeals in 1999 which established that the meaning of 'community standards' was broad in defining harmful material. In 2002, the Supreme Court reviewed this judgement, and found the evidence insufficient, and then it referred it to the circuit court which approved it for the second time the law for being unconstitutional considering it as a violation of freedom of opinion in the US Constitution. $^{67}$

c The Congress issued the Children's Internet Protection Act (CIPA) in 2000 to address the concerns about the access of children to obscene or harmful content online. ${ }^{68}$ This Act imposes several requirements on schools and libraries that wish to get discounts for internet access or internal connections through rate $\mathrm{E}$ (a program which makes some telecommunications services and products more affordable for eligible schools and libraries).

Schools and libraries may be deprived by this Act of those discounts unless they have effective policy of internet safety which includes measures of technology protection, these measures should include protection against accessing the internet containing obscene photos, pornographic material that is harmful to minors. The adoption of a policy of internet safety became enforceable.

Also, this Act contains requirements for provision of additional certificate when they are able to monitor the online activities of minors in accordance with CPA the 21st century, which requires providing appropriate guidance to minors about appropriate conduct in the use of the internet, including interaction with other individuals on social networking websites and chat rooms.

The Act requires schools and their libraries to adopt and implement the safety policy that contains the following points:

1 access by minors to inappropriate websites on the internet

2 safety and security of minors when using electronic mail, chat rooms, and other forms of direct electronic communications

3 unauthorised access, including so-called 'hacking' and other unlawful activities by minors online

4 unauthorised disclosure, use, and publication of personal information regarding minors

5 taking measures that restrict access by minors to harmful materials. ${ }^{69}$

\subsubsection{Australia}

One can understand the fight against human trafficking via the internet in Australia through the brief policy pursued by the Australian Government and the resulted legislation in this regard. As in the USA, the Australian Criminal Act of 1999 (and as amended in 2005) indicates elements of the crime of sexual slavery and scam employment (leading to the human trafficking). ${ }^{70}$ These amendments aimed to renew the legal provisions on slavery subject to the developments of international human trafficking, particularly the sexual exploitation. As a result, the Act combined provisions criminalising those who deliberately or in default try to enslave others for sexual 
exploitation, by imprisonment sentence up to 25 years, and by imprisonment up to 12 years for those who participate or assist any act of human trafficking. ${ }^{71}$ The Act gives the victims the right to an appropriate visa to enter Australia without requiring their financial capacities to sue against their offenders. ${ }^{72}$

Unlike the policy followed in the USA which prohibits restrictions on the use of electronic means of communication, the Australian Government aims to control the publication of internet content that is in violation of decency within its territory. For this reason, Australia has enacted its Broadcasting Services Act of $1992^{73}$ which determined the three varieties of online content which the service providers must refrain from publishing, the most important of which represents those containing harmful material for the youth under the age of 18 , and providing that sexual pictures or sexual violence are prohibited from being broadcast, giving the Australian Communications and Media Authority the right to investigate any violation and to encrypt any suspicious published data. $^{74}$

\subsection{Arab legislations relating to human trafficking via the internet}

It is intended to address the most relevant Arab legislations in human trafficking via the internet in this section. This shall include the legislations of Saudi Arabia, the UAE, Jordan and Qatar.

\subsubsection{Saudi Arabia}

In comparison to the number of internet users, Saudi Arabia is one of the first ten states that suffers from electronic spams being initiated on its territory. ${ }^{75}$ Accordingly, the Kingdom managed to issue a new regulation to fight cyber crimes and issued a Royal Decree No. $\mathrm{m} / 17$ on $8 / 3 / 1428 \mathrm{AH},{ }^{76}$ which contained a definition of terms including the term 'cyber crime' defining it as "any act committed with the use of a computer or cyber network in violation of the provisions of this law". ${ }^{77}$ Article 6 of this Act states that: "any person who commits any of the following cyber crimes shall be punished with imprisonment for not more than five years and a fine of not more than three million riyals, or either of them:

1 producing any material that may prejudice the public order, religious values, morals or privacy, prepare, submit or store it through the cyber network or using a computer

2 creating a website, or a computer or to publish for human trafficking, or to facilitate the deal

3 creating material and data related to porn networks, or the facilitator's activities violating morals or publishing or promoting thereof".

It can be said that the provisions of these articles demonstrate the inclusiveness of all types of crimes related to the use of the internet, including the trafficking of all types to the extent that article 6 included human trafficking, directly or indirectly, holding anyone who publishes human trafficking punishable as well as the creation of the related websites and the related data and material. However, this Act is criticised for not introducing deterrent punishment for this crime and did not single out specific counter punishment for those who participate in such crimes. 


\subsubsection{The United Arab Emirates}

The UAE Federal Decree-Law No. (5) of 2012 of 13 August 2012 on Combating Cyber Crimes, ${ }^{78}$ whereby the UAE Federal Law No. 2/2006 was repealed, is one of the pioneer laws in the Arab region in this regard. The previous law, unlike the Saudi Act on cyber crimes, has provided for more detailed provisions on human trafficking crimes. ${ }^{79}$ Article 17 of the previous law provided that "everyone who established websites, or post information on the internet, or any means of information technology, with a view to human trafficking or facilitating the deal, shall be punished with temporary imprisonment", the amendment in article 23 of the Law states that: "Shall be punished by temporary imprisonment and a fine not less than five hundred thousand dirhams and not in excess of one million dirhams or either of these two penalties whoever establishes, administer or runs a website or publishes information on a computer network or any information technology means for the purpose of trafficking in humans or human organs or dealing in them illegally".

Article 13 of the previous Law provides that anyone who instigates male or female to commit prostitution or debauchery, or helps him using the internet or any of the means of information technology, shall be punished by imprisonment or payment of a fine. In case the victim was a minor, the imprisonment shall not be less than five years and to pay a fine, whilst article 12 stipulates that everyone who produces, prepares, makes available, sends or stores with a view to exploit, distribute, or supply to others via the internet, or any means of information technology, which would undermine public morals, or managed a premises for this purpose, shall be punished with imprisonment and payment of a fine or both. If the Act is committed by a minor, the punishment shall be imprisonment of not less than six months and payment of a fine not less than 30,000 AED. Article 20 of the amended Law states that "Without prejudice to the crime of slander determined by the Islamic Sharia, shall be punished by imprisonment and a fine not less than two hundred fifty thousand dirhams and not in excess of five hundred thousand dirhams or either of these two penalties whoever insults or accuses another person of a matter of which he shall be subject to punishment or being held in contempt by others, by using a computer network or an information technology means. If a slander or insult is committed against a public official or servant in the course of or because of his work, this shall be considered an aggravating factor of the crime".

Indeed, the UAE legislator has issued its 2012 Decree-Law in view of the rapid development in information technology. This Decree-Law is considered the most recent legislation in the Arab region although only a complement Law on crimes that have basis in the Penal Law. This Law, for example, emphasised the protection of the rights and freedoms of internet users out of providing social and ethical protection for the society. In comparison with the Federal Criminal Law No. 3 of 1987, which stated in article 363 that: "anyone who instigates or incites male or female using any means to commit fornication or prostitution or helped him on that, shall be punished with imprisonment for not less than one year and payment of fine", the 2012 Law states that "Shall be punished by imprisonment and a fine not less than two hundred fifty thousand dirhams and not in excess of one million dirhams or either of these two penalties whoever entices, aids or abets another person, by using a computer network or any information technology means, to engage in prostitution or lewdness... The punishment shall be imprisonment for a period of at least five years and a fine not in excess of one million dirhams if the victim is a juvenile under the age of eighteen years of age". This indicates that the new law has 
safeguarded the right of freedom of opinion and in consistency with the Federal Criminal Act.

\subsubsection{The Hashemite Kingdom of Jordan}

Despite the fact that the Jordanian legislator has issued Law No. 9 of 2009 which prevents human trafficking, it has nonetheless made no reference to the crimes of human trafficking via the internet. Accordingly, the Cyber Crime Law of 2010 was enacted $^{80}$ to provide in article 9 (a) that "anyone who intentionally sends or publishes using information system, or the internet, any audio, printed or visual materials that are contrary to morals or that prejudice someone under 18 years of age, shall be punished with imprisonment for not less than three months and with the payment of fine of no less than three hundred JD and no more than five thousand JD." Article 9 (b) states that: "anyone who intentionally uses information system, or the internet to save, process, display, print, publish or promote pornographic activities or acts relating to incitement of those who are under 14 years old, or exploiting them in prostitution and pornography, libel, or sell them, or inciting them to act the same, or used them to commit a crime, shall be punished with imprisonment for no less than six months and a fine of not less than 500 JD and no more than five thousand JD".

It is noted that these articles are related to the protection of children and minors from sexual exploitation in particular in conformity with the provision of article 306 of the Jordanian Penal Act. It is also noted that the Jordanian legislator has criminalised "all acts that are contradictory to morals and are directed to the minors by using electronic means, due to the fact that the websites, email, and other electronic means are easy to be accessed by minors without supervision and without knowing their sources sometimes". 81

Article 10 of the Jordanian law has held as criminal anyone who intentionally uses the internet for promotion of prostitution or fornication. The aim of this article is to prevent exploitation of the tremendous technological advances prostitution on the internet.

\subsubsection{The State of Qatar}

Recently, the Qatari legislator has made attempts combat online crime of all forms. As such, the Qatari Cabinet has newly approved a law in combating the electronic crimes and has referred it to the Shura Council. It can be said that this law aims to punish whomsoever "has access by the internet or any of the means of information technology, to any website or information system belonging to the state or its institutions, bodies, entities or affiliates, and all whosoever has established or managed a website via the internet or any of the means of information technology, to publish false news with intent to endanger the safety of the state, its public order or its internal or external security, as well as punishing whosoever infringes any of the social principles or values, or published news, images, or audio or video materials violating the privacy of the people private and family life, even they were true, or has insulted others by insult or slander, via the internet or any other means of information technology". 82

Owing to the lack of explanatory memorandum from the national legislator on this new law, the law itself has not been issued till now; it is therefore difficult to identify the most important topics that will be covered by this law specifically what to what matters to combatting trafficking in humans through the internet. 
Despite the fact that the Qatari legislator has allocated certain room for the subject of computer crimes in chapter 5 of the Criminal Act of 2004, however, the chapter mentioned nothing on crimes related to human trafficking via the internet, all the contained provisions centered on automated data-processing system, fraud thereof, sending viruses and the misuse of magnetic bank cards.

\section{Conclusions}

Human trafficking via the internet is a serious violation of human beings' rights, dignity and freedom; it is an international phenomenon which has negative effects on all international community. Accordingly, states have sought to create political and legal solutions to prevent and fight human trafficking via the internet, including the United Nations, Council of European Union, Arab League in their pursuit to develop legislation to taken as an initial reference on the criminalisation of human trafficking.

As many European countries, and some of Arab countries, have issued legislations on internet crimes which contained some legal provisions on fighting human trafficking, it can nonetheless be noted that these agreements and legislations ignored the subject of human trafficking via the internet, or they were inadequate to address the phenomenon of human trafficking via the internet. Therefore, it appears that there is an urgent need for the international community to adopt a special Convention in this regard. Although there are some clear signs to oblige states to adopt legislative and practical means to confront human trafficking crimes, states generally, in varying proportions, still lack in taking the required actions.

It is clear that it was necessary that legislations must keep pace with the significant development in the cyber crimes, considering it as an urgent need to deal with the crime, through non-traditional legal rules required to confront this type of non-traditional crimes. There has emerged the need for a comprehensive confrontation in line with these crimes, including human trafficking. So, some states, such as Saudi Arabia, Jordan and the United Arab Emirates have developed a legislation to fight e-crimes and to address human trafficking, focusing on sexual crimes and crimes concerning children using technological means. However, some other Arabic countries, such as Qatar, Bahrain, Egypt and Palestine, still have no legislations on this type of e-crimes, and depend only on the Penal Laws or other legislation, such as the Children's Laws or Anti-Prostitution Laws, in the fight of these crimes. For example, as stated previously, the fifth chapter of the Penal Law of Qatar has provisions on computer crimes in particular, without any reference to human trafficking via the internet.

Hence, in order to fill the gap in the field of fighting human trafficking via the internet, one must monitor the means of filling in the current legislative shortfalls; as it is not enough to determine the dimensions of the problem under consideration without suggesting the appropriate means to resolve this problem. Briefly, the most important axes of these solutions are as follows:

1 To codify new rules for fighting human trafficking crimes on the internet, taking into account the special nature of this type of crime, in particular in relation to the evidence in cases arising from such crimes. This legislation should be issued allowing the competent authorities to follow the e-mails, in addition to any other means that may be useful in proving the crime and get a clue, and revealing the truth, 
investigations procedures should be extended to any other computer systems that could be relevant to the suspected system and seizing any related information. We must work to find a logical balance between the individuals' right to access information through technological means and the state's right to maintain public morality in society as a public right.

2 To incorporate the necessary amendments to the rules of criminal procedures in accordance with this type of crime, and to the extent that sets out the provisions to be followed when monitoring computers and when seizing the information contained therein and seizing e-mails in order to have a reasoned proof.

3 To ensure international cooperation, in fighting human trafficking over the internet on the level of jurisdiction and procedures.

4 To notice the urgent need for incorporating the appropriate amendments to the Penal Act and the Act on prevention of human trafficking to suit the content of rules on criminalising human trafficking via electronic means, in particular, the criminalisation of the use of children in the film that uses them in indecent scenes, to be viewed on the internet or using email.

5 To explicitly criminalise unauthorised access to e-mail to send pornographic pictures.

6 There is an urgent need for the legislation on internet crimes for Acts concerning the introduction of all harmful conducts to the community using the internet.

7 Citizens must engage in fighting human trafficking via the internet through enacting the appropriate legislations to make them engage in monitoring and fighting such crime.

8 To add a special course titled 'internet ethics' into the curricula of basic education and add a university course for law colleges to study legal protection on the internet and its criminal uses.

9 To adhere to the Arab Convention on fighting cyber crimes considering it as a supporting input for the enactment of laws to fight internet crimes.

\section{Notes}

1 Adopted in Warsaw in 2005 and came into force on 1 February 2008 and was ratified by 20 states.

2 See, International Labor Office (2008) Combatting Forced Labor: A Handbook for Employees \& Business, Part I, Introduction \& Overview, Vol. 15, p.13 [online] http://www.webcitation.org/5o882919C (accessed on 5/8/2013).

3 See UN Documentation [online] http://www.un.org/en/documents/index.shtml/ (accessed on 5/8/2013).

4 See ILO Report of 1998 [online] http://www.ilo.org/legacy/arabic/dialogue/ifpdial/llg/index.htm (accessed on 5/8/2013).

5 Kara, S. (2009) Sex Trafficking: Inside the Business of Modern Slavery, Columbia University Press.

6 Belser, P. (2005) Forced Labor and Human Trafficking: Estimating the Profits, Intl. Labor Office, Working Paper No. 42, p.4. 
7 United Nations (2003) Combating Human Trafficking in Asia: A Resource Guide to International and Regional Legal Instruments Political Commitments and Recommended Practices, Thailand, UN, p.15.

8 Thomas, R. (20013) 'Love bug virus is no Herbie', The Business Journal [online] http://www.thepbj.com (accessed on 4/9/2013).

9 Johnson, D.R. (1996) Law and Borders - The Rise of Law in Cyberspace, Stanford Law Review, Stanford, Vol. 48, p.1367-1402.

10 See in particular the situation in Thailand, p.143 [online] http://www.humantrafficking.org/countries/eap/thailand/ (accessed on 14/8/2013).

11 See Alhmood, W.M. and AlMajali, N.M. (2005) The Crimes of Internet, Dar Almanar Press, Amman, Arabic Text, p.62.

12 Brian C. Lewis, Prevention of Computer Crime Amidst International Anarchy, 41 AM. CRIM. L. REV. at 1355.

13 Treaty Doc. No. 108-11, 2001 WL 34368783, 41 I.L.M. 282, C.E.T.S. No. 185.

14 See the explanatory report of the European Council on the Convention on Cyber Crime, No. 6, September 2001 [online] http://www.webcitation.org/5oockmhYp (accessed on 10/9/2013).

15 For example, 250 criminals were enlisted as serious criminals for indecent acts which mainly materialised through their use of the internet and were apprehended as pedophiles. See AlRiyadh Newspaper, Sunday, 5 August 2007, Ser. 14286, p.39.

16 Signed on 18 May1904.

17 The Convention for the suppression of trafficking in women and children was ratified by 27 states.

18 The Convention for the suppression of trafficking in persons and the exploitation of the prostitution was adopted on 2 December 1949, by the ONU Resolution 317 (IV).

19 UN Doc. A/RES/55/25.

20 Many Directives have been issued by the European Union since the early 1990s that focused on preventing human trafficking through the adoption of certain criminal legislative procedures and coordination between the judiciary systems of EU countries. These aimed at limiting the scope of crimes and cooperation in apprehending criminals and to providing assistance to victims of human trafficking.. These include: Recommendation No. R (91) on sexual exploitation, pornography and prostitution of, and trafficking in, children and young adults; Recommendation No. R (97) 13 concerning intimidation of the witnesses and the rights of the defense; Recommendation No. R (2000) 11 on action against trafficking in human beings for the purpose of sexual exploitation; Recommendation Rec (2001) 16 on the protection of the children against sexual exploitation; Recommendation Rec (2002) 5 on women protection against violence. Recommendations passed by the Council of Europe also include: Recommendation 1.325 (1997) on women trafficking and forced prostitution in the member states of the Council of Europe; Recommendation 1.450 (2000) on violence against women in Europe; Recommendation 1.545 (2002) on the campaign against trafficking in women; Recommendation 1.610 (2003) on migration related to trafficking in women and prostitution; Recommendation 1.611 (2003) on trafficking in organs in Europe; Recommendation 1.663 (2004) on domestic slavery: servitude, au pairs and mail-order brides. Also, consider the European Legal Framework Against Trafficking of 19 July 2002 in respect of the fight against trafficking in human beings; the Decision of Council in respect of the European Legal Framework on the standing of victims in criminal proceedings; and the Directive of the Council of the European Union of 29th April 2004 on the residence title issued to third countries' citizens that are victims of trafficking in human beings or who were involved in an action to facilitate illegal migration, and who cooperate with the competent authorities.

21 Council of Europe Convention on Action against Trafficking in Human Beings, CETS No.: 197. Source: Treaty Office [online] http://conventions.coe.int/. Adopted in Warsaw in 2005 and came into force on 1 February 2008 and was ratified by 20 states. 
22 See in this respect the EC Plan related to the best practices, indicators and procedures to prevent trafficking in humans, Official Gazette, 9/12/2015, No. 2005/c311/01.

23 As to the international cooperation in preventing and fighting the phenomenon of human trafficking, one can also conclude that the international community has paid a special interest in this subject: from preventing and fighting the crime to the actual help needed for victims of human trafficking; providing guarantees of equality between the two sexes; and the necessary course of legal and legislative action in criminalising specific human trafficking crimes; strengthening the investigation and fact-finding procedures; cooperation between countries with respect to having control over their international borders; and due documentation to ensure the prevention of transition of investments that rely on human trafficking, have all been covered in various provisions.

24 These questions are always going to pose a challenge, and indeed are an obstacle in the way of the elimination of human trafficking, or even the production of a coherent research into this topic. The difficulty here lies mostly in either the lack of specialised statistics on this matter or the doubted credibility of issued reports, if any. States are still announcing incorrect details or figures about these crimes, and most likely attempt to show how thriving their internal measures adopted to suppress this crime. Adding this to the fact that international law rules akin to human trafficking are not as developed as they should, rendering the whole effectiveness of international law governing such cross-border crime almost doubtful, reflects the importance of giving special priority to this subject in the various fields of research and analysis.

25 In 2002, the United States Department of Justice approximated that some 50,000 women were trafficked into the United States alone for the purposes of commercial sex. This number does not include women trafficked domestically between or within US states. Press Release, Dept. of Justice, Dept. of Justice Issues T Visa to Protect Women, Children and All Victims of Human Trafficking (24 January 2002) [online] http://www.webcitation.org/5o89UalmS.

268 U.S.C. $\S 1101$.

27 Bales, K. (2009) Modern Slavery: The Secret World of 27 Million People, Oneworld.

28 Gallagher, A. (2009) 'Human rights and human trafficking: quagmire or firm ground? A response to James Hathaway', Virginia Journal of International Law, Vol. 49, No. 4.

29 Kara, Supra note 5, at p.226.

30 Ibid.

31 Priddy, J., United States Internet Sex Slaves [online] http://www.associatedcontent.com, archived at, http://www.webcitation.org/5pyVM6ilr. Also, Council of Europe, Convention on Cyber Crime, Explanatory Report, 6, 23 November 2001, S. Treaty Doc. No. 108-11, 2001 WL 34368783, 41 I.L.M. 282, C.E.T.S. No. 185 [hereinafter Explanatory Report] [online] $\mathrm{http} / / / \quad$ conven-tions.coe.int/Treaty/en/Treaties/Html/185.htm, archived at http://www.webcitation.org/5oockmhYp (accessed on the 14 September 2013).

32 United Nations Conference on Trade and Development, Information Economy Report 2005, UNCTAD/SDTE/ECB/2005/1, 2005, Chapter 6, p.233 [online] http://www.unctad.org/en/docs/sdteecb20051ch6_en.pdf (accessed on the 26/9/2013).

33 See more at http://news.bbc.co.uk/2/hi/science/nature/38009.stm.

34 For more analysis in this see Labki, G. (2013) 'International internet treaties: facts and challenges', AlDifaa Alwatani Journal, Arabic text [online] https://groups.google.com/forum/\#!topic/fayad61/PdLd8Gy0xJM (accessed on 5/8/2013).

35 Ibid, and also [online] http://www.ibls.com/internet_law_news_portal_view_prn.aspx?s=latestnews\&id=1882 (accessed on 5/8/2013).

36 The last quarter of the year 2013 has proved to be full of events for the INTERPOL Global Complex for Innovation (IGCI). For instance, in November alone, four IGCI meetings took place in Singapore under the title 'the 15th INTERPOL Group of Experts Meeting on Information Technology Crime, Asia and South Pacific'; 'the 1st Eurasian Working Group on Cybercrime for Heads of Units'; 'the 3rd Operational Expert Group on Cybercrime (OEGC)'; 
and 'the 9th IGCI Working Group'. See information available on $\mathrm{http}: / /$ www.google.com/url? sa=t\&rct=j\&q=\&esrc=s\&frm=1\&source=web\& $\mathrm{cd}=2 \& v e d=0 \mathrm{CCs}$ QFjAB\&url=http $\% 3 \mathrm{~A} \% 2 \mathrm{~F} \% 2 \mathrm{Fwww}$.interpol.int $\% 2 \mathrm{~F}$ content $\% 2 \mathrm{Fdownload} \% 2 \mathrm{~F} 23673 \% 2 \mathrm{~F} 22$ 4420\%2Fversion $\% 2 \mathrm{~F} 5 \% 2 \mathrm{Ffile} \% 2 \mathrm{FNewsletter} 9 . \mathrm{pdf} \& \mathrm{ei}=\mathrm{dEdGU} 56 \mathrm{yBcis} 7 \mathrm{Qbel} 4 \mathrm{HIDQ} \& u$ s $=$ AFQjCNHii-KZav1a8x93jA7Y-3qTyEOCnQ (accessed on 10/4/2014).

37 Text in http://www.un.org/ga/search/view_doc.asp?symbol=A/RES/45/121\&Lang=E\&Area=RESOL UTION.

Text in http://www.un.org/depts/dhl/resguide/r55_en.shtml.

39 Ibid.

40 Ibid.

41 For further analysis see AlObaidi, O. (2013) 'Child prostitution via the internet: a comparative study', AlShareea WalQanoon Journal, Ser. 53, January.

42 ITU Global Cybersecurity Agenda, High-Level Experts Group, Global Strategic Report [online] http://www.itu.int/osg/csd/cybersecurity/gca/global-strategic-report/index.html (accessed on the 8/10/2013).

43 Ibid.

44 Supra note 19.

45 Condoleezza Rice, Secretary, US Department of State, Letter from the Secretary, 1 Trafficking in Persons Report: June 2007, published by US Department of State [hereinafter 2007 Trafficking in Persons Report]. See also: Anti-Slavery, Frequently Asked Questions, 9 March 2010 [online] http://www.antislavery.org, archived at http://www.webcitation.org/5o6ye9MXc (accessed on the 5/8/2013).

46 Anti-Slavery, Frequently Asked Questions, 9 March 2010 [online] http://www.antislavery.org, archived at: http://www.webcitation.org/5o6ye9MXc (accessed on 5/8/2013).

47 See Alhmood, W.M. and AlMajali, N.M., Supra note, pp.197-199.

48 The Convention is available on the website of the Council of Europe [online] $\mathrm{http}: / /$ conventions.coe.int/Treaty/en/Treaties/Html/185.htm (accessed on 30/9/ 2013). See analysis of this Convention Vatis, M.A., The Council of Europe Convention on Cyber Crime, Steptoe \& Johnson LLP, Proceedings of a Workshop on Deterring Cyber Attacks: Informing Strategies and Developing Options for U.S. Policy: http://www.nap.edu/catalog/12997.html.

49 The Convention was drafted by the Council of Europe (COE) in Strasbourg, France. In addition to COE Member states, Canada, Japan, South Africa, and the United States participated in the negotiation of the Convention as observers. 26 EU Member States have joined this Convention, along with Japan, the United States, South Africa and Canada. It is the first Convention on crimes committed through the Internet. This Convention is open for join by all States even those non-European ones.

50 See Convention on Cyber Crime, Supra note 47, Art. 14(2)(c).

51 Ibid, Arts. 18-21.

52 See analysis in Ahmad, H.A. (2007) Budapest Convention for Combating Cyber Crimes, Dar Alnahdha AlArabia, 1st ed., Cairo, Arabic Text, pp.109-112.

53 See UK Computer Misuse Act of 1990 [online] http://www.legislation.gov.uk/ukpga/1990/18/contents (accessed on 22/9/2013).

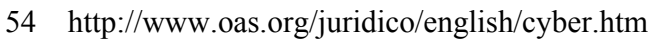

55 See analysis in Nassar, M., The Cyber Crime [online] http://www.iasj.net/iasj?func=fulltext\&aId=28397 (accessed on 12/9/2013).

56 Text of Convention can be found [online] http://conventions.coe.int/Treaty/en/Treaties/Html/108.htm.

57 Text of Convention [online] http://www.arablealnet.org (accessed on 13 September 2013).

58 The Preamble of the Convention, Ibid. 
59 Council of Europe Cyber Crime Convention, Arts. 7 and 8.

60 The 2004 Model Arab Law on Combating Offences related to Information Technology Systems [online] http://unipd-centrodirittiumani.it/en/spilli/Arab-League-conventionsregarding-fields-from-human-rights-and-peace/153.

61 See Article 30 of the Convention.

62 Konkol, M.J. (2009) 'Cook county sheriff sues craigslist for sex ads', CHICAGO SUNTIMES, 6 March.

63 The Court passed its judgment on November 2009 on behalf of Craigslist on the basis that the company is not responsible for the third party illegal acts not it should be liable for the misuse of their websites by individuals. Dart v. Craigslist, Inc., 665 F. Supp. $2 d 961$ (N.D. Ill. 2009). Also see on this case Walberg, M. (2009) 'Sheriff Sues Craigslist as 'largest source' of prostitution', Chicago Breaking News, Vol. 4, 5 March 2009 [online] http://www.webcitation.org/5o5489MCj.

64 See in this respect Green v. America Online, 318 F.3d 465, 470 (3d Cir. 2003); Batzel v. Smith, 333 F.3d 1018, 1036 (9th Cir. 2003); Universal Communication Systems, Inc. v. Lycos, Inc., 478 F.3d 413, 418 (1st Cir. 2007).

65 Telecommunications Act of 1996, 47 U.S.C. $§ 230(\mathrm{~b})(2)(2006)$.

66 In 1996, Philadelphia panel of federal judges blocked part of the CDA, saying that it would infringe upon the free speech rights of adults. A month later, the New York federal court struck down the portion of the CDA intended to protect children from indecent speech as too broad. In 1997, the Supreme Court upheld the Philadelphia court's decision in Reno v. American Civil Liberties Union on the basis that the indecency provisions were an unconstitutional abridgement of the First Amendment right to free speech because they did not permit parents to decide for themselves what material was acceptable for their children, extended to non-commercial speech, and did not define 'patently offensive', a term with no prior legal meaning. (The New York case, Reno v. Shea, was affirmed by the Supreme Court the next day, without a published opinion). Reno v. ACLU, 521 U.S. 844, 845-46 (1997).

67 See ACLU v. Ashcroft, 322 F.3d 240, 265-67 (2003).

68 See analysis in Report to Congress, Children's Internet Protection Act, Pub. L. 106-554, Study of Technology Protection Measures in Section 1703, August 2003, Department of Commerce, National Telecommunications and Information Administration.

69 See details [online] http://www.fcc.gov/guides/childrens-internet-protection-act (accessed on $5 / 8 / 2013$ )

70 In discussing the impact of combatting human trafficking in Australia see: Andreas Schloenhardt, Slavery, Sexual Servitude, and Deceptive Recruiting Offences: Division 270 Criminal Code (Cth), University of Queens Lamd: human Trafficking Working group, Oct. 10, 2009, at: http://www.webcitation.org/5owJuVPGF. (Last accessed on 5/8/2013)

71 See Australian Criminal Act of 2005 which provides that Criminal Acts on Children is penalised by 20 years of imprisonment.

72 Ibid.

73 Australian Communications and Media Authority, Broadcasting Services Act of 1992 [online] $\mathrm{http}: / /$ www.webcitation.org/5oow9ItJ0 (accessed on 5/8/2013).

74 See: Electronic Frontiers Australia (2006) Internet Censorship Laws in Australia, 31 March [online] http://www.efa.org.au/Issues/censor/cens1.html (accessed on 5/8/2013).

75 Report in AlSharq AlAwsat Newspaper [online] http://www.aawsat.com (accessed on 10/9/2013).

76 As a conclusion of the decision of the Council of Ministers No.79 dated 7/3/1428 AH. See Text, Arabic Text [online] http://www.citc.gov.sa/arabic/RulesandSystems/CITCSyste/Documents/LA_004_\%20A_\%20 Anti-Cyber\%20Crime\%20Law.pdf (accessed on 20 September 2013).

77 Article 1 of the Saudi Arabia Cyber Crime Regulation of 2007, Ibid. 
78 Text in http://www.binsevanadvocates.com/media_center.php?news $=40$ (accessed on 15/September/2013).

79 For a comprehensive analysis in the amendments made to this law see: Mustafa, K.H. (2013) Electronic Publishing Services and their Criminal Liabilities for the Misuse of Social Media, Roaa Istrateejiya, Arabic Text, March.

80 The Jordanian Cabinet has introduced several amendments in 2010 to the draft of the Information System Crimes Law (Cyber Crime Law) to meet some the demands of lawyers and website owners in Jordan.

The Cabinet approved on 3 August 2010 the first Cyber Crime Law in Jordan. The temporary law was issued by the Ministry of Information and Communication Technology and will take effect after 30 days of its issuance if approved by the king. The law was prepared and was issued primarily to address a legal vacuum in new digital crimes that the Jordanian criminal law could not address effectively, and to provide trust over internet networks for internet users. The law was heavily criticised by Jordanian bloggers, website owners, the National Centre for Human Rights and the Committee to Protect Journalists.

81 See the Explanatory Report of the Cyber Crime Law, Arabic Text [online] http://www.slideshare.ne (accessed on 5/8/2013).

82 See, Arabic Text [online] http://www.bna.bh/portal/news/563044. (Last accessed on $8 / 9 / 2013)$ 